\title{
EFFICIENCY OF TWO FORMULATIONS OF THE PATHOGENIC FUNGI, BIOSECT (Beauveria bassiana) AND BIORANZA (Metarhizium anisopliae) AGAINST LARVAE OF Spodoptera littoralis (BOISD.) AND Agrotis ipsilon (HFN.) (LEPIDOPTERA: NOCTIDAE) \\ EL- Garhy, S. M. M. \\ Plant Protiction Res. Inst., Agric. Res. Centre, Dokki, Giza, Egypt.
}

\begin{abstract}
Laboratory tests and a semi-field trial were carried out to determine the efficiency of two commercial preparations of the entomopathogenic fungi, Beauveria bassiana and Metarhizium anisopliae namely; Biosect w.p., and Bioranza10 \% w.p., against the first instar larvae of the cotton leaf worm, Spodoptera littoralis (Boisd.) and, Agrotis ipsilon (Hfn.) (Lepedoptera: Noctuidae). Newly hatched, one- day and two- day old larvae of the two insects were allowed to feed on castor oil leaves (100 gram / replicate) treated with different concentrations of the two entomopathogenic fungi for $48 \mathrm{hrs}$ at three different temperatures, 20,25 and $30^{5} \mathrm{C}$. Mortality rate increased by increasing the concentration, or post treatment period and temperature. Newly hatched larvae were the most sensitive to the toxic effect especially at highest concentration and temperature $\left(30^{5} \mathrm{C}\right)$, while the two- day old larvae were the most tolerant and the one-day old larvae expressed a moderate tolerance. S. littoralis was more sensitive than $A$. ipsilon. Calculated $L_{50 \text { s }}$ values for initial mortality of the newly hatched larvae were $(0.458,0.309$ and $0.279 \mathrm{mg} / \mathrm{ml}$. when treated with Biosect and $\left(0.676,0.352\right.$ and 0.317 when treated with Bioranza) at 20,25 and $25{ }^{5} \mathrm{C}$, respectively. Consumed castor oil leaves were decreased by increasing the concentration and temperature but were lower than the control.

Keywords : Spodoptera littoralis, Agrotis ipsilon, Beauveria bassiana, Metarhizium anisopliae, Efficiency.
\end{abstract}

\section{INTRODUCTION}

Over-reliance on broad-spectrum pesticides had come under severe criticism from different parts of the world. An alternative eco-friendly strategy for the management of noxious insect pests has been searched to reduce harmful effects of chemical insecticides on environment and humanity. In recent years, crop protection based on biological control of crop pests, with microbial pathogens like virus, bacteria, fungi and nematodes has been recognized as a valuable tool in pest management (Bhattacharya et al., 2003).

The appropriate use of environment-friendly microbial pesticides can play a significant role in sustainable crop production by providing a stable pest management program. Among the fungi, several asexual fungi are associated with Arthropods, especially with insects Entomopathogenic fungi that parasitize insects are valuable weapons for biocontrol and play an important role in promoting integrated pest management, El-Hawary et al., (2009). 
The use of biological agents to control pests has been known and practiced for long time. Many of the ready made biological control formulations were tested and achieved higher mortality for $S$. littoralis and $A$. ipsilon larval stages as Bacillius thuringiensis (Hosny et al., 1993). Biological formulations, Bisect and Bioranza are safe to human beings and animals, and do not cause environmental pollution or harmful effects for natural enemies. In this concern, the development of fungal control agents, Beauveria bassiana and Metarhizium anisopliae for possible use against some key lepidopterous pests received a great attention during the last two decades (Kao 2007).

The successful use of the two biological control agents, Biosect w.p (32 x 106 spores / gm. wp) and Bioranza10 \% w.p (32 x 106 spores / gm. wp) is to control $S$. littoralis and $A$. ipsilon received great attention than chemical control. The present investigation evaluates the effect of the two commercial preparations of Biosect W.P. and Bioranza10 \% W.P. on the first instar larvae of $S$. littoralis and $A$. ipsilon.

The significance of study is to illustrate the ability of fungi conidiospores to exhibit positive influences on larval mortality as well as malformation in different stages of treated $S$. littoralis and $A$. ipsilon.

\section{MATERIALS AND METHODS}

\section{Insect culture:}

Insect larvae used were obtained from laboratory strains of $\boldsymbol{S}$. littoralis and $A$. ipsilon reared on castor oil leaves for several generations under controlled conditions of $25 \pm 2^{5} \mathrm{C}$ and $65 \pm 5 \%$ R.H at Department of Entomology, Faculty of Agriculture, Fauoum University.

\section{Bio- insecticide preparations:}

Two commercial products of Biosect w.p, $\left(32 \times 10^{6}\right.$ conidia/ $\left.\mathrm{ml} \mathrm{l}\right)$, recommended concentration is $200 \mathrm{gm} / 100$ liters of water and Bioranza10 $\%$ W.P., $\left(32 \times 10^{6}\right.$ spore/gm w.p), recommended concentration is $200 \mathrm{gm} / 100$ liters of water.

\section{Bioassay technique:}

Five serial dilutions of the two bioinsecticides were prepared at five concentrations, $0.10,0.25,0.5,0.75$, and $1.0 \mathrm{mg} / \mathrm{ml}$ for the two aforementioned insect pests. Tests were done by weighing $100 \mathrm{gram}$ of castor, dipping in each of different concentrations and left until completely dried. Three age-groups of $1^{\text {st }}$ instar larvae were tested; newly hatched, 1day old and 2- day old. For every concentration, forty larvae of each agegroup were provided with treated castor leaves for $48 \mathrm{hrs}$ on 20,25 and $30^{5} \mathrm{C}$ then transferred to untreated leaves to continue feeding on the same aforementioned temperatures. $\mathrm{LC}_{50}$ values were calculated to each concentration as mentioned above. Consumed quantities for each age-group larvae at different concentrations and abovementioned temperatures were calculated. Larvae of the check were reared at the seame laboratory conditions but on untreated leaves. 


\section{Bioresidual effect:}

Forty age- group $1^{\text {st }}$ instar larvae as replicates was allowed to feed on $100 \mathrm{gr}$. of castor leaves treated with each of the two formulations; Biosect and Bioranza at the concentrations of $\mathrm{LC}_{50}$ of each of the concentrations at 20,25 and $30{ }^{5} \mathrm{C}$. Three replicates were prepared as control.

\section{Semi- field trails:}

In the field, 10 pots of $25 \mathrm{~cm}$ were sown by cotton seeds, each had 5 plants of 30 days old and spread on each concentrations as replicate. Double concentrations were used, $(2 \times 0.1),(2 \times 0.25),(2 \times 0.5),(2 \times 0.75)$ and $(2 \times$ $1.0 \mathrm{mg} / \mathrm{ml}$ ). Three replicates were prepared as control per treatment, each had 10 pots. The three age- groups, newly hatched, one- day old and 2- day old larvae were applied at the rate of 2 larvae / plant in a cage. Pots in cages were covered by a shade net of 250 mish under simulated field conditions.

The same technique was used for both insect pests to the two formulations at the abovementioned concentrations. The field trail was checked after 5, 7 and 10 days. Twenty five infested leaves per replicate were collected randomly in paper page and transferred to the laboratory.

\section{Statistical analysis:}

LC $_{50}$ slop values and fiducial limits of mortality rates were statistically calculated using a Proban Software Computer Program. In addition, the persistence of each biocide was studied in the laboratory on the three agegroups at the concentrations of $\mathrm{LC}_{50 \mathrm{~s}}$ on the aforementioned temperatures. Toxicity index (Ti) was determined by using Sun's equation (1950) as follows:

$$
\text { Toxicity index }(\mathrm{Ti})=\frac{\mathrm{LC}_{50}\left(\mathrm{LC}_{90}\right) \text { of the compound } \mathrm{A}}{\mathrm{LC}_{50}\left(\mathrm{LC}_{90}\right) \text { of compound } \mathrm{B}} \times 100
$$

Where $A$ is the most effective compound.

$\mathrm{B}$ : is the other tested compound.

Mortality percentages were calculated according to the following equation:

$$
\begin{aligned}
& \% \text { Reduction of infestation }=\frac{\mathrm{C}-\mathrm{T}}{\mathrm{C}} \times 100 \\
& \text { Where, } \mathrm{C}=\text { Estimated parameter in the control. } \\
& \mathrm{T}=\text { Same parameter in the treatment. }
\end{aligned}
$$

\section{RESULTS AND DISSCUSION}

As presented in table (1) presents the results of feeding $1^{\text {st }}$ instar larvae of $S$. littoralis, on various concentrations of the two formulations of Beauveria bassiana and Metahizium anisopliae. Obtained data indicated that the two formulations had great effects on the three age-groups of $1^{\text {st }}$ instar larvae. A positive relationship existed between larval mortality and concentration. For $S$. littoralis, the mortality rates were $(68.4$, 74.3and $76.1 \%)$ of the newly hatched larvae after $48 \mathrm{hr}$, at the highest concentration $(1.0 \mathrm{mg} /$ $\mathrm{ml}$ ) of Bisect, accompanied with high consumptions (22.3, 28.5 and 38.9 
grams) and (60.3, 70.3 and 73.1\%) in Bioranza with consumptions of (25.5, 30.1 and $32.7 \mathrm{gr}$.), at 20,25 and $30{ }^{5} \mathrm{C}$, respectively.

Table (1): Efficiency of Biosect and Bioranza formulations on $1^{\text {st }}$ instar larvae S. littoralis at 20,25 and $30{ }^{5} \mathrm{C}$ under laboratory conditions.

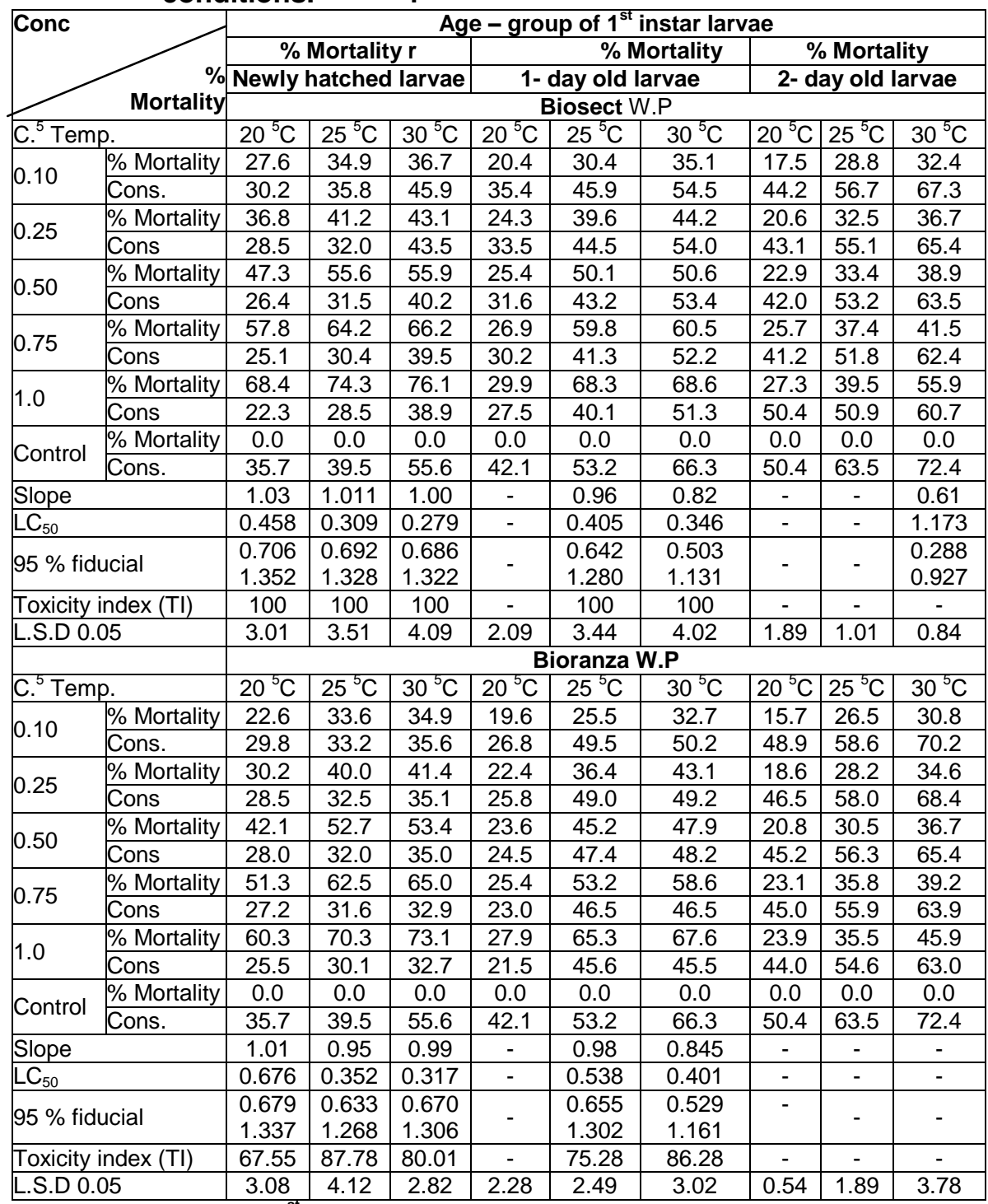

N.B: Forty age - groups $1^{\text {st }}$ instar larvae were exposed.

The mortality rates were $(27.6,34.9$ and $36.7 \%)$ with the consumption of (30.2, 35.8 and 45.9 gr.) of Bisect and (22.6, 33.6 and $40.1 \%$ ) with the consumption of (22.6, 33.6 and $34.9 \mathrm{gr}$.) of Bioranza, respectively, at the lowest concentration $(0.1 \mathrm{mg} / \mathrm{ml})$ of the two formulations. Older larvae ( 1 and 
2-day old) seemed to be more resistant to the two tested formulations caused $20.4,30.4$ and $35.1 \%$ mortality to one day old larvae after $48 \mathrm{hrs}$. with the consumptions of $(35.4,45.9$ and $54.5 \mathrm{gr}$.) and $(17.5,28.8$ and $32.4 \%)$ with the consumptions of $(44.2,56.7$ and $67.3 \mathrm{gr}$.) for the two day old larvae. The highest concentration caused 29.9, 68.3 and $68.6 \%$, with the consumptions of (27.5, 40.1 and $51.3 \mathrm{gr}$.) to the former age-group and (27.3, 39.5 and 55.9 $\%)$ with the consumptions of $(50.4,50.9$ and $60.7 \mathrm{gr}$.), respectively, to the latter age-group on the abovementioned temperatures.

Table (1) shows also that larval mortality rates were related to the concentration and temperature. The mortality rates increased to $27.6,34.9$ and 36.7 , to $20.4,30.4$ and 35.1 , and $17.5,28.8$ and $32.4 \%$ in the treatment of the newly hatched, 1-day and 2-day old larvae at the lowest concentration of Biosect $10 \%$ W.P), respectively. At the highest concentration, the mortality rates reached to $68.4,74.3$ and $76.1,29.9,68.3$ and $68.6,27.3,39.5$ and $55.9 \%$, respectively. On the other hand, the mortality rates for (Bioranza10 \%) were 22.6, 33.6 and 34.9, 19.6, 25.5 and 32.7, and 15.7, 26.5 and $30.8 \%$ at the lowest concentrations and $60.3,70.3$ and 73.1, and 27.9, 65.3 and 67.6 , and $23.9,35.5$ and $45.9 \%$ at the highest one.

These findings agree with Gomaa and Ibrahim 2006 who reported that both formulations were effective on the 2- and 4 instar larvae of $S$. littoralis. Farag, 2008 tested Bonanza, Biovar products, Delfin wg, and NeemAzal-T/S on the $3^{\text {rd }}$ instar larvae of $S$. littoralis. Biovar induced the highest percentage of mortality, followed by Bioranza.

As for A. ipsilon, $1^{\text {st }}$ instar larvae seemed to be more tolerant to the adverse effect of Biosect than $S$. littoralis. Considerable mortality among treated larvae was recorded at 20,25 and $30^{5} \mathrm{C}$. As in S. littoralis, mortality rates were positively related to the concentration of any of the two tested formulations and temperatures while they were negatively related to the larval age. Data in table (2) revealed that, the newly hatched larvae treated with Biosect and Bioranza concentrations expressed different rates of mortality; $17.8-62.5$ with the consumptions of $(40.8-30.2 \mathrm{gr}$.) and $15.7-60.4 \%(35.2$ -27.6 gr.) , respectively, at $20^{5} \mathrm{C}$ from treatment, with increase of larval age to 1-day old larvae, mortality percentages rates increased to ( $15.8-27.4$ and $15.0-25.5 \%)$ with consumptions of $(45.9-40.2$ and $39.8-32.6)$ for Biosect and Bioranza, respectively. Further decrease in mortality was observed in 2 day old larvae, $14.9-25.8$ and $13.9-22.9 \%$ with the consumptions of $(67.3-59.6$ and $45.2-40.0$ gr.), respectively.

Increase of mortality among treated larvae as a percentage of corrected mortality recorded was $71.3-74.2,65.3-65.6$ and $37.5-51.5 \%$ with the consumptions of $(47.3-62.1,50.1-53.2$ and $63.5-73.5)$ at 25 and $30^{5} \mathrm{C}$ after treatment of newly hatched, $1-$ day and 2- day old larvae with highest concentration of Biosect, respectively. Corresponding mortalities for Bioranza were 70.5 - 74.0, $63.4-63.8$ and 35.6 - $50.1 \%$, with the consumptions of $(35.0-41.0,40.7-40.2$ and $68.0-72.0)$, respectively. 
Table (2): Efficiency of Biosect and Bioranza formulations on $1^{\text {st }}$ instar larvae of A.ipsilon under different controlled temperatures under laboratory conditions.

\begin{tabular}{|c|c|c|c|c|c|c|c|c|c|c|}
\hline \multirow{3}{*}{\multicolumn{2}{|c|}{ Conc. }} & \multicolumn{9}{|c|}{ Age - group of $1^{\text {st }}$ instar larvae } \\
\hline & & \multicolumn{3}{|c|}{$\%$ Mortality $\mathbf{r}$} & \multicolumn{3}{|c|}{$\%$ Mortality } & \multicolumn{3}{|c|}{$\%$ Mortality } \\
\hline & & \multicolumn{3}{|c|}{ Newly hatched larvae } & \multicolumn{3}{|c|}{ 1- day old larvae } & \multicolumn{3}{|c|}{ 2- day old larvae } \\
\hline \multicolumn{11}{|c|}{\begin{tabular}{|l} 
Biosect W.P \\
\end{tabular}} \\
\hline \multicolumn{2}{|c|}{ C. ${ }^{5}$ Temp. } & $20^{5} \mathrm{C}$ & $25^{5} \mathrm{C}$ & $30{ }^{5} \mathrm{C}$ & $20{ }^{5} \mathrm{C}$ & $25^{5} \mathrm{C}$ & $30^{5} \mathrm{C}$ & $20^{5} \mathrm{C}$ & $25^{5} \mathrm{C}$ & $30^{5} \mathrm{C}$ \\
\hline \multirow{2}{*}{0.10} & $\%$ Mortality & 17.8 & 22.6 & 28.4 & 15.8 & 22.3 & 23.5 & 14.9 & 20.9 & 21.5 \\
\hline & Cons.. & 40.8 & 55.4 & 68.5 & 45.9 & 56.8 & 60.5 & 67.3 & 72.5 & 82.5 \\
\hline \multirow{2}{*}{0.25} & $\%$ Mortality & 35.2 & 40.3 & 42.5 & 23.2 & 31.5 & 35.8 & 19.5 & 28.3 & 30.7 \\
\hline & Cons. & 38.5 & 53.5 & 66.1 & 43.5 & 54.2 & 58.6 & 65.9 & 70.2 & 80.1 \\
\hline \multirow{2}{*}{0.50} & $\%$ Mortality & 45.1 & 53.8 & 54.9 & 24.2 & 40.2 & 45.2 & 20.7 & 30.4 & 34.5 \\
\hline & Cons. & 35.4 & 51.2 & 64.8 & 43.0 & 53.0 & 56.8 & 63.2 & 68.1 & 78.6 \\
\hline \multirow{2}{*}{0.75} & $\%$ Mortality & 54.9 & 62.4 & 61.8 & 25.1 & 55.7 & 57.7 & 23.7 & 34.6 & 39.4 \\
\hline & Cons. & 32.5 & 50.0 & 63.2 & 41.0 & 51.4 & 55.0 & 61.8 & 65.4 & 75.9 \\
\hline \multirow{2}{*}{1.0} & $\%$ Mortality & 62.5 & 71.3 & 74.2 & 27.4 & 65.3 & 65.6 & 25.8 & 37.5 & 51.5 \\
\hline & Cons. & 30.2 & 47.3 & 62.1 & 40.2 & 50.1 & 53.2 & 59.6 & 63.5 & 73.5 \\
\hline \multirow{2}{*}{ Control } & $\%$ Mortality & 0.0 & 0.0 & 0.0 & 0.0 & 0.0 & 0.0 & 0.0 & 0.0 & 0.0 \\
\hline & Cons. & 45.7 & 60.2 & 75.4 & 50.6 & 65.7 & 73.5 & 68.9 & 80.1 & 95.4 \\
\hline \multicolumn{2}{|l|}{ Slope } & 1.19 & 1.27 & 1.14 & - & 1.13 & 1.10 & - & - & 0.73 \\
\hline \multicolumn{2}{|l|}{$\mathrm{LC}_{50}$} & 0.574 & 0.397 & 0.351 & - & 0.585 & 0.511 & - & - & 1.326 \\
\hline \multicolumn{2}{|c|}{$95 \%$ fiducial } & $\begin{array}{l}0.860 \\
1.528\end{array}$ & $\begin{array}{l}0.942 \\
1.599\end{array}$ & $\begin{array}{l}0.818 \\
1.464\end{array}$ & - & $\begin{array}{l}0.801 \\
1.464\end{array}$ & $\begin{array}{l}0.772 \\
1.426\end{array}$ & - & - & $\begin{array}{l}0.401 \\
1.058\end{array}$ \\
\hline \multicolumn{2}{|c|}{ Toxicity index (TI) } & 100 & 100 & 100 & - & 100 & 100 & - & - & 100 \\
\hline \multicolumn{2}{|c|}{ L.S.D 0.05} & 2.14 & 3.66 & 4.23 & 1.79 & 2.89 & 3.11 & 1.22 & 0.89 & 1.01 \\
\hline \multicolumn{11}{|c|}{ Bioranza W.P } \\
\hline \multicolumn{2}{|c|}{ C. ${ }^{5}$ Temp. } & $20^{5} \mathrm{C}$ & $25^{5} \mathrm{C}$ & $30^{5} \mathrm{C}$ & $20^{5} \mathrm{C}$ & $25^{5} \mathrm{C}$ & $30^{5} \mathrm{C}$ & $20^{5} \mathrm{C}$ & $25^{5} \mathrm{C}$ & $30^{5} \mathrm{C}$ \\
\hline 010 & $\%$ Mortality & 15.7 & 20.4 & 26.1 & 15.0 & 20.9 & 21.6 & 13.9 & 19.1 & 20.5 \\
\hline 0.10 & Cons. & 35.2 & 40.2 & 47.6 & 39.8 & 45.2 & 47.5 & 45.2 & 72.4 & 80.6 \\
\hline & $\%$ Mortality & 33.9 & 38.6 & 40.4 & 21.2 & 29.6 & 33.2 & 17.8 & 26.7 & 28.7 \\
\hline 0.25 & Cons. & 32.5 & 37.2 & 45.6 & 38.2 & 44.2 & 46.0 & 44.5 & 70.2 & 75.4 \\
\hline & $\%$ Mortality & 43.1 & 50.2 & 52.0 & 22.3 & 37.8 & 42.5 & 19.5 & 27.8 & 33.5 \\
\hline 0.50 & Cons. & 31.4 & 36.5 & 44.1 & 36.9 & 43.0 & 44.6 & 41.8 & 70.0 & 75.0 \\
\hline & $\%$ Mortality & 51.9 & 60.5 & 69.5 & 23.2 & 53.7 & 56.7 & 21.5 & 32.7 & 37.5 \\
\hline 0.15 & Cons. & 28.7 & 35.2 & 42.3 & 34.9 & 42.0 & 41.9 & 40.5 & 68.7 & 72.3 \\
\hline & $\%$ Mortality & 60.4 & 70.5 & 74.0 & 25.5 & 63.4 & 61.8 & 22.9 & 35.6 & 50.1 \\
\hline 1.0 & Cons. & 27.6 & 35.0 & 41.0 & 32.6 & 40.7 & 40.2 & 40.0 & 68.0 & 72.0 \\
\hline & $\%$ Mortality & 0.0 & 0.0 & 0.0 & 0.0 & 0.0 & 0.0 & 0.0 & 0.0 & 0.0 \\
\hline Control & Cons. & 45.7 & 60.2 & 75.4 & 50.6 & 65.7 & 73.5 & 68.9 & 80.1 & 95.4 \\
\hline Slope & & 1.20 & 1.30 & 1.30 & - & 1.13 & 1.13 & - & - & 0.73 \\
\hline $\mathrm{LC}_{50}$ & & 0.642 & 0.439 & 0.354 & - & 0.651 & 0.567 & - & - & 1.498 \\
\hline $95 \%$ fid & ucial & $\begin{array}{l}0.863 \\
1.539\end{array}$ & $\begin{array}{l}0.970 \\
1.634\end{array}$ & $\begin{array}{l}0.970 \\
1.626\end{array}$ & - & $\begin{array}{l}0.798 \\
1.468\end{array}$ & $\begin{array}{l}0.796 \\
1.457\end{array}$ & - & - & $\begin{array}{l}0.402 \\
1.065\end{array}$ \\
\hline Toxicity & index (TI) & 89.4 & 90.43 & 99.15 & - & 89.86 & 90.12 & - & - & 88.52 \\
\hline L.S.D 0. & & 2.06 & 2.77 & 4.01 & 1.63 & 2.41 & 2.99 & 1.11 & 0.78 & 0.89 \\
\hline
\end{tabular}

N.B: Forty age - groups $1^{\text {st }}$ instar larvae were exposed.

Regarding the cumulative mortality after treatment of $S$. littoralis, newly hatched and 1-day old larvae showed higher mortality percentages at all concentrations at $20^{5} \mathrm{C}$ of treatment, Table. 1. Mortality continued according to pathogen concentration. At higher and lower concentrations, most larvae died within $30^{5} \mathrm{C}$. 
It could be stated, therefore, that exposing larvae to 25 , and $30^{5} \mathrm{C}$ caused more mortality among the three age group larvae. Accordingly, highest percentages rates of mortality occurred at different tested concentrations at $30^{5} \mathrm{C}$. Treatment of 2-day old larvae, at the highest concentration of Biosect $(1.0 \mathrm{mg} / \mathrm{ml})$ showed lower initial mortality $(27.3 \%)$ rate than the newly hatched $(68.4 \%)$ or 1-day old larvae $(29.9 \%)$, respectively, table 1.

EL-Hawary et al., (2009) evaluated the efficiency of the entomopathogenic fungi products, Bio- Power (B. bassiana), Bio-Catch (Lecanicillium lecanii) and Priority (Paecilomyces fumosoroseus)) against $S$. littoralis and $A$. ipsilon larvae under laboratory conditions at the concentrations of $0.125 \times 10^{9}, 0.250 \times 10^{9}, 0.5 \times 10^{9}$ and $1 \times 10^{9}$ and found that Bio- Power was the most effective and calculated $\mathrm{LC}_{50}$ and $\mathrm{LC}_{90}$ were $0.2 \times 10^{9}$ and $1.5 \times 10^{9}$, respectively. Gosselin, et al., (2009) found that the entomopathogenic fungus, $B$. bassiana had a lower efficacy, with an estimated $\mathrm{LC}_{50}$ of $7 \times 107$ spores $\mathrm{mL}-1$. on third instar larvae of $A$. ipsilon.

As for A.ipsillon, table (2) larval mortality rates continued to increases progressively within increased temperatures. Comparison between $S$. littoralis and $A$. ipsilon indicated that mortality rate started later, but continued faster in the case of $A$. ipsilom as no progressive mortality occurred at $25^{5} \mathrm{C}$ with 1 and 2-day old larvae of $A$. ipsillon, using lowest concentration of Biosect.

Data in tables (1 and 2) show that the activity of the two pathogens formulations not differed for the two considered pests according to the larval age. Based on the $\mathrm{LC}_{50}$ values and toxicity index (Ti), Biosect was more toxic (the $\left.\mathrm{LC}_{50}=0.458 \mathrm{mg} / \mathrm{ml} \& \mathrm{Ti}=100\right),(0.309 \mathrm{mg} / \mathrm{ml} \& \mathrm{Ti}=100)$ and $(0.279$ $\mathrm{mg} / \mathrm{ml} \& \mathrm{Ti}=100)$ to the newly hatched larvae of $S$. littoralis than Bioranza (the $\left.\mathrm{LC}_{50}=0.676 \mathrm{mg} / \mathrm{ml} \mathrm{\&} \mathrm{Ti}=67.55\right),(0.352 \mathrm{mg} / \mathrm{ml} \mathrm{\&} \mathrm{Ti}=87.78)$ and $\left(0.317 \mathrm{mg} / \mathrm{ml} \& \mathrm{Ti}=80.01\right.$, as presented at 20,25 and $30{ }^{5} \mathrm{C}$. As for Bisect on $A$. ipsilon newly hatched larvae $\left(\mathrm{LC}_{50}\right.$, were $\left.0.574 \mathrm{mg} / \mathrm{ml} \& \mathrm{Ti}=100\right)$, $(0.397 \mathrm{mg} / \mathrm{ml} \& \mathrm{Ti}=100)$ and $(0.351 \mathrm{mg} / \mathrm{ml} \& \mathrm{Ti}=100)$ and Bioranza was less effective $\left(\mathrm{LC}_{50}=0.642 \mathrm{mg} / \mathrm{ml} \& \mathrm{Ti}=89.4\right),(0.439 \mathrm{mg} / \mathrm{ml} \& \mathrm{Ti}=90.43)$ and $(0.354 \mathrm{mg} / \mathrm{ml} \& \mathrm{Ti}=99.15)$. Levels of toxicity were determined on some cotton insect pests by many investigators (Sabbour and Sahab 2005; Gardezi, 2006 and Garcia 2010).

Statistical analysis of the obtained data showed significant differences in $S$. littoralis and $A$. ipsilon infestation between the two testing formulations. Bioresidual effect:

As presented in table (3) mortality percentages were recorded at several concentrations on the aforementioned temperatures. The mortality percentages of treated $S$. littoralis newly hatched,1-day old and 2- day old larvae at the lowest concentration of Biosect at 20,25 and $30^{5} \mathrm{C}$ were 12.7,10.1 and 7.0, 14.9, 14.0 and 13.4, 16.8, 16.0 and 15.0. The percentages of mortality increased at higher concentration to 21.9, 20.8 and 15.7 and 25.7, 21.6 and 20.6 and $27.5,25.9$ and 28.7 , respectively. The mortality percentages of the newly hatched larvae were $12.7-21.9,14.9-25.7$ and $16.8-27.5$ at the aforementioned temperatures. Older larvae ( 1 and 2-day 
old) seemed to be more resistant to Biosect while the mortality percentages increased to $10.1-20.8,14.0-21.6$ and $16.0-25.9$ and $7.0-15.7,13.4-$ 20.6 and $15.0-28.7$, respectively.

S. littoralis seemed to be tolerant to Bioranza. Obtained data were 12.5,10.4 and 10.0, 16.5, 14.3and 12.7, 19.7, 18.7 and 16.4with the lower concentration $(0.1 \mathrm{mg} / \mathrm{ml})$ and increased to $19.8,18.5$ and 18.0, 22.1, 22.0 and $21.5,45.7,33.4$ and 30.2 to the three age-groups, at tested temperatures at highest concentration $(1.0 \mathrm{mg} / \mathrm{ml})$, respectively. The newly hatched larvae seemed to be sensitive than the two other age- groups. The mortality percentages ranged $12.5-19.8,16.5-22.1$, and $19.7-45.7$ and decreased mortality percentages were obtained by 1 - day and 2- day larvae and ranged $10.4-18.5,13.4-22.0,18.7-33.4$ and $10.0-18.5,12.7-21.5$, and $16.4-$ $30.2 \%$, at 20,25 and $30{ }^{5} \mathrm{C}$, respectively. S. littoralis was susceptible to the fungi; $B$. bassiana and $M$. anisopilae and respective $L_{50} S$ values for $S$. littoralis were: $163 \times 10^{4}$ and $175 \times 10^{4}$ spores $/ \mathrm{ml}$. (Sahab and Sabbour 2011).

Table (3): Persistene of Biosect and Bioranza formulations at $\mathrm{LC}_{50 \mathrm{~s}}$ on $1^{\text {st }}$ instar larvae $S$. littoralis under different controlled temperatures.

\begin{tabular}{|c|c|c|c|c|c|c|c|c|c|c|}
\hline \multirow[t]{4}{*}{ Conc } & & \multicolumn{9}{|c|}{ Age - group of $1^{\text {st }}$ instar larvae } \\
\hline & \multirow[b]{3}{*}{ Mortality } & \multicolumn{3}{|c|}{$\%$ Mortality r } & \multicolumn{3}{|c|}{$\%$ Mortality } & \multicolumn{3}{|c|}{$\%$ Mortality } \\
\hline & & \multicolumn{3}{|c|}{$\begin{array}{l}\text { Newly hatched } \\
\text { larvae }\end{array}$} & \multicolumn{3}{|c|}{ 1- day old larvae } & \multicolumn{3}{|c|}{ 2- day old larvae } \\
\hline & & \multicolumn{9}{|c|}{ Biosect W.P } \\
\hline C. ${ }^{5}$ Tem & & $20^{5} \mathrm{C}$ & $25^{5} \mathrm{C}$ & $30{ }^{5} \mathrm{C}$ & $20{ }^{5} \mathrm{C}$ & $25^{5} \mathrm{C}$ & $30{ }^{5} \mathrm{C}$ & $20^{5} \mathrm{C}$ & $25^{5} \mathrm{C}$ & $30^{5} \mathrm{C}$ \\
\hline \multirow{2}{*}{0.10} & $\%$ Mortality & 12.7 & 14.9 & 16.8 & 10.1 & 14.0 & 16.0 & 7.0 & 13.4 & 15.0 \\
\hline & Cons. & 32.4 & 37.5 & 48.6 & 37.6 & 48.7 & 55.4 & 46.8 & 58.9 & 69.5 \\
\hline \multirow{2}{*}{0.25} & $\%$ Mortality & 15.4 & 18.6 & 18.7 & 12.4 & 16.9 & 19.5 & 8.5 & 15.2 & 17.5 \\
\hline & Cons & 29.5 & 35.0 & 45.8 & 35.1 & 46.8 & 52.6 & 43.8 & 55.5 & 65.4 \\
\hline \multirow{2}{*}{0.50} & $\%$ Mortality & 18.4 & 20.4 & 22.4 & 13.8 & 18.5 & 20.1 & 8.6 & 19.4 & 21.7 \\
\hline & Cons & 26.4 & 32.1 & 42.3 & 33.4 & 43.5 & 50.4 & 41.3 & 52.4 & 62.7 \\
\hline \multirow{2}{*}{0.75} & $\%$ Mortality & 20.6 & 22.1 & 23.5 & 18.9 & 19.8 & 21.4 & 12.5 & 14.2 & 23.0 \\
\hline & Cons & 23.1 & 30.6 & 39.4 & 31.8 & 40.5 & 47.3 & 39.7 & 50.7 & 60.0 \\
\hline \multirow{2}{*}{1.0} & $\%$ Mortality & 21.9 & 25.7 & 27.5 & 20.8 & 21.6 & 25.9 & 15.7 & 20.6 & 28.7 \\
\hline & Cons & 20.3 & 25.3 & 35.8 & 30.9 & 38.0 & 44.7 & 36.5 & 45.8 & 59.4 \\
\hline \multirow{2}{*}{ Control } & $\%$ Mortality & 0.0 & 0.0 & 0.0 & 0.0 & 0.0 & 0.0 & 0.0 & 0.0 & 0.0 \\
\hline & Cons. & 35.7 & 39.5 & 55.6 & 42.1 & 53.2 & 66.3 & 50.4 & 63.5 & 72.4 \\
\hline & & \multicolumn{9}{|c|}{ Bioranza W.P } \\
\hline \multicolumn{2}{|c|}{ C. ${ }^{5}$ Temp. } & $20^{5} \mathrm{C}$ & $25^{5} \mathrm{C}$ & $30{ }^{5} \mathrm{C}$ & $20{ }^{5} \mathrm{C}$ & $25^{5} \mathrm{C}$ & $30^{5} \mathrm{C}$ & $20^{5} \mathrm{C}$ & $25^{5} \mathrm{C}$ & $30^{5} \mathrm{C}$ \\
\hline \multirow{2}{*}{0.10} & $\%$ Mortality & 12.5 & 16.5 & 19.7 & 10.4 & 13.4 & 18.7 & 10.0 & 12.7 & 16.4 \\
\hline & Cons. & 32.4 & 35.4 & 35.6 & 26.8 & 49.5 & 50.2 & 48.9 & 58.6 & 70.2 \\
\hline \multirow{2}{*}{0.25} & $\%$ Mortality & 13.9 & 17.6 & 21.9 & 12.9 & 14.4 & 21.9 & 12.6 & 18.6 & 18.9 \\
\hline & Cons & 35.2 & 39.3 & 38.4 & 28.9 & 53.4 & 55.4 & 50.3 & 60.3 & 72.3 \\
\hline \multirow{2}{*}{0.50} & $\%$ Mortality & 17.5 & 19.8 & 24.5 & 18.0 & 15.5 & 23.4 & 15.2 & 20.5 & 25.4 \\
\hline & Cons & 37.9 & 41.0 & 41.6 & 29.6 & 56.3 & 56.6 & 52.4 & 63.4 & 75.4 \\
\hline \multirow{2}{*}{0.75} & $\%$ Mortality & 19.4 & 20.4 & 25.7 & 18.4 & 20.0 & 29.8 & 16.5 & 20.9 & 27.5 \\
\hline & Cons & 39.7 & 43.1 & 45.8 & 31.5 & 60.0 & 62.1 & 55.1 & 65.4 & 77.9 \\
\hline \multirow{2}{*}{1.0} & $\%$ Mortality & 19.8 & 22.1 & 45.7 & 18.5 & 22.0 & 33.4 & 18.5 & 21.5 & 30.2 \\
\hline & Cons & 42.1 & 45.6 & 48.7 & 34.5 & 63.5 & 65.0 & 60.2 & 66.1 & 80.4 \\
\hline \multirow{2}{*}{ Control } & $\%$ Mortality & 0.0 & 0.0 & 0.0 & 0.0 & 0.0 & 0.0 & 0.0 & 0.0 & 0.0 \\
\hline & Cons. & 35.7 & 39.5 & 55.6 & 42.1 & 53.2 & 66.3 & 50.4 & 63.5 & 72.4 \\
\hline
\end{tabular}

N.B: Forty age - groups were exposed. 
Older larvae (1 and 2-day old) seemed to be more resistant to Biosect the mortality percentages were increased to $8.2-26.8,11.9-29.9$ and $12.8-36.6$ and $7.0-16.5,10.6-24.5$ and $11.9-33.0$, on 20, 25 and $30^{5} \mathrm{C}$, respectively, obtained data also indicated that the newly hatched larvae were the most sensitive than the two other age-group under laboratory conditions.

Obtained data in table 4 shows that the mortality percentages of $A$. ipsilon with Biosect at the lowest concentration of Biosect $\left(\mathrm{LC}_{50}\right.$ of the concentration of $(0.1 \mathrm{mg} / \mathrm{ml})$ were $8.5,8.2$ and $7.0,12.1,11.9$ and 10.6, 15.2, 12.8 and $11.9 \%$ increased to $38.7,26.8$ and $16.5,42.1,29.9$ and $24.5,12.8$ - 36.6, $7.0-16.5,10.6-24.5$ and $11.09-33.0 \%$ against the three age groups, respectively.

On the other hand, the mortality percentages with Bioranza $\mathrm{LC}_{50 \text { s }}$ of A. ipsilon at the lowest concentration were 7.5, 7.2 and 7.0,14.5, 10.8 and 10.,17.6, 14.5 and $11.2 \%$ increased to $43.8,31.8$ and 25.3, 47.6, 35.7 and $29.9,48.0,38.6$ and $36.5 \%$ at the highest concentration on the three agegroups.

Newly hatched larvae seemed to be more sensitive than the two agegroups larvae and the recorded mortality percentages ranged $7.5-43.8,14.5$ - 47.6, 17.6 - $48.0,7.2$ - $31.8,10.8$ - 35.7, 14.5 - 38.6, 7.0 - 25.3, 10.1 29.9 and $11.2-36.5 \%$ at the three age-groups, respectively.

\section{Semi-field trial assessment:}

Tabulated data in table (5) show that the lower concentration $(2 \times 0.1$ $\mathrm{mg} / \mathrm{ml}$ ) achieved lowest mortality percentages vice versa was the highest one $(2 \times 1.0 \mathrm{mg} / \mathrm{ml})$ of Biosect on $S$. littoralis. The mortality percentages at the concentration of $2 \times 0.1$ after 5,7 and 10 days were 70.0, 50.0 and 42.0 and $76.0,56.0$ and 50.0 and 84.068 .0 and $56.0 \%$, respectively. At the highest concentration, the mortality percentages were 90.0, 66.0 and 62.0 and $92.0,72.0$ and 70 and $94.0,86.0$ and $80.0 \%$ after the same periods. Survival rat was $100 \%$ and the mortality percentages were $0.0 \%$, in the control. A significant decrease in the population of $S$. littoralis larvae was recorded after one week from application of Biosect on peanut. The first instar was zero in all treatments compared with control (309 control was 3.9 larvae/day on the same date) (Zaki and Abdel-Raheem 2010).

In addition, the mortality percentages at the lower concentration of Bioranza were 56.0, 48.0 and 32.0, 64.0, 52.0 and 36.0, 72.0, 60.0 and $44.0 \%$. The mortality percentages at the concentration of the highest one were 69.0, 64.0 and 53.0, 83.0, 67.0 and 61.0, 88.0, 83.0 and $72.0 \%$ while the survival rate of the three age groups of $S$. littoralis after 5,7 and 10 days was $100 \%$ in the control.

These results agree with those obtained by Sahab and Sabbour (2011) who reported that under field conditions, the tested fungi showed significant infestations' decrease in the plots treated with $B$. bassiana, followed by M. anisopliae. El-Husseini et al., (2008) bioassay $B$. bassiana in two formulations; for spraying and dusting applications, in sugar beet fields for controlling S. littoralis and other chewing pests. They reported that Pests feed by chewing all leaf tissues showed high reduction rates whatever the 


\section{EL- Garhy, S. M. M.}

applied technique, i.e. the noctuid larvae of $S$. littoralis, Trichoplusia ni, Antographa gamma and Syngrapha circumflexa [Cornutiplusia circumflexa].

Amer at al., (2008) studied the ability of fungi, B. bassinet and $M$. anisopliae conidiospores to exhibit positive influences on larval mortality as well as malformation in different stages of $S$. littoralis treated. These effects showed that, the mortality percentage increased with increasing concentrations and time elapsed after treatment.

Table (4): Persistence of Biosect and Bioranza formulations at the concentrations of $\mathrm{LC}_{50 \mathrm{~s}}$ on $1^{\text {st }}$ instar larvae of $A$. ipsilon under different controlled temperatures under laboratory conditions.

\begin{tabular}{|c|c|c|c|c|c|c|c|c|c|c|}
\hline \multirow{3}{*}{\multicolumn{2}{|c|}{$\begin{aligned} \text { Conc. } & \\
& \% \text { mortality. }\end{aligned}$}} & \multicolumn{9}{|c|}{ Age - group of $1^{\text {st }}$ instar larvae } \\
\hline & & \multicolumn{3}{|c|}{$\%$ Mortality } & \multicolumn{3}{|c|}{$\%$ Mortality } & \multicolumn{3}{|c|}{$\%$ Mortality } \\
\hline & & \multicolumn{3}{|c|}{ Newly hatched larvae } & \multicolumn{3}{|c|}{ 1- day old larvae } & \multicolumn{3}{|c|}{ 2- day old larvae } \\
\hline \multicolumn{11}{|c|}{ Biosect W.P } \\
\hline C. ${ }^{5}$ Tem & & $20{ }^{5} \mathrm{C}$ & $25^{5} \mathrm{C}$ & $30{ }^{5} \mathrm{C}$ & $20{ }^{5} \mathrm{C}$ & $25^{5} \mathrm{C}$ & $30{ }^{5} \mathrm{C}$ & $20{ }^{5} \mathrm{C}$ & $25^{5} \mathrm{C}$ & $30{ }^{5} \mathrm{C}$ \\
\hline \multirow{2}{*}{0.10} & $\%$ Mortality & 8.5 & 12.1 & 15.2 & 8.2 & 11.9 & 12.8 & 7.0 & 10.6 & 11.9 \\
\hline & Cons. & 41.5 & 56.8 & 62.5 & 46.7 & 58.4 & 63.5 & 68.6 & 73.2 & 86.4 \\
\hline \multirow{2}{*}{0.25} & $\%$ Mortality & 18.2 & 21.5 & 23.1 & 13.4 & 17.2 & 18.7 & 10.6 & 14.0 & 15.1 \\
\hline & Cons. & 43.4 & 57.4 & 63.5 & 48.9 & 60.2 & 65.4 & 70.2 & 75.6 & 88.7 \\
\hline \multirow{2}{*}{0.50} & $\%$ Mortality & 26.4 & 27.3 & 30.4 & 15.9 & 20.9 & 23.1 & 13.6 & 17.5 & 18.9 \\
\hline & Cons. & 45.8 & 59.4 & 66.4 & 50.1 & 63.5 & 68.4 & 73.5 & 76.4 & 88.9 \\
\hline \multirow[b]{2}{*}{0.75} & $\%$ Mortality & 29.8 & 36.8 & 36.5 & 23.6 & 26.7 & 31.1 & 15.4 & 21.1 & 26.5 \\
\hline & Cons. & 48.8 & 60.7 & 67.9 & 52.3 & 65.4 & 70.1 & 73.9 & 78.9 & 90.5 \\
\hline \multirow{2}{*}{1.0} & $\%$ Mortality & 38.7 & 42.1 & 42.9 & 26.8 & 29.9 & 36.6 & 16.5 & 24.5 & 33.0 \\
\hline & Cons. & 51.3 & 63.5 & 70.7 & 55.2 & 66.0 & 70.6 & 75.4 & 80.6 & 91.7 \\
\hline \multirow[b]{2}{*}{ Control } & $\%$ Mortality & 0.0 & 0.0 & 0.0 & 0.0 & 0.0 & 0.0 & 0.0 & 0.0 & 0.0 \\
\hline & Cons. & 55.4 & 65.8 & 75.4 & 60.8 & 70.0 & 76.4 & 77.4 & 85.1 & 95.6 \\
\hline \multicolumn{11}{|c|}{ Bioranza W.P } \\
\hline \multicolumn{2}{|c|}{ C. ${ }^{5}$ Temp. } & $20{ }^{5} \mathrm{C}$ & $25^{5} \mathrm{C}$ & $30{ }^{5} \mathrm{C}$ & $20{ }^{5} \mathrm{C}$ & $25^{5} \mathrm{C}$ & $30{ }^{5} \mathrm{C}$ & $20^{5} \mathrm{C}$ & $25^{5} \mathrm{C}$ & $30{ }^{5} \mathrm{C}$ \\
\hline \multirow{2}{*}{0.10} & $\%$ Mortality & 7.5 & 14.5 & 17.6 & 7.2 & 10.8 & 14.5 & 7.0 & 10.1 & 11.2 \\
\hline & Cons. & 36.0 & 41.1 & 48.0 & 40.1 & 46.1 & 48.5 & 46.4 & 73.5 & 81.6 \\
\hline \multirow{2}{*}{0.25} & $\%$ Mortality & 17.1 & 25.9 & 29.6 & 14.2 & 17.2 & 21.0 & 7.5 & 15.4 & 18.3 \\
\hline & Cons. & 36.4 & 43.5 & 48.0 & 41.3 & 46.8 & 48.6 & 47.2 & 74.5 & 82.3 \\
\hline \multirow{2}{*}{0.50} & $\%$ Mortality & 30.4 & 39.3 & 36.8 & 18.9 & 22.2 & 27.3 & 11.2 & 19.1 & 26.4 \\
\hline & Cons. & 38.7 & 44.2 & 50.2 & 41.2 & 47.6 & 50.2 & 48.7 & 75.6 & 83.4 \\
\hline \multirow{2}{*}{0.75} & $\%$ Mortality & 39.0 & 43.2 & 44.2 & 26.7 & 31.1 & 33.8 & 18.2 & 25.6 & 30.4 \\
\hline & Cons. & 41.0 & 45.5 & 53.2 & 42.1 & 48.9 & 52.1 & 49.6 & 77.5 & 85.6 \\
\hline \multirow{2}{*}{1.0} & $\%$ Mortality & 43.8 & 47.6 & 48.0 & 31.8 & 35.7 & 38.6 & 25.3 & 29.9 & 36.5 \\
\hline & Cons. & 44.3 & 46.8 & 55.5 & 43.9 & 50.1 & 54.1 & 50.1 & 78.6 & 87.2 \\
\hline \multirow{2}{*}{ Control } & $\%$ Mortality & 0.0 & 0.0 & 0.0 & 0.0 & 0.0 & 0.0 & 0.0 & 0.0 & 0.0 \\
\hline & Cons. & 45.9 & 48.3 & 56.5 & 43.5 & 52.1 & 57.2 & 53.4 & 80.2 & 88.7 \\
\hline
\end{tabular}

N.B: Forty age - groups were exposed. 
Table (5): Efficiency of Biosect and Bioranza formulations on S. littoralis age - group larvae under semi- field conditions.

\begin{tabular}{|c|c|c|c|c|c|c|c|c|c|c|}
\hline \multirow{4}{*}{\multicolumn{2}{|c|}{ Conc. }} & \multicolumn{9}{|c|}{ Age - group of $1^{\text {st }}$ instar larvae } \\
\hline & & \multirow{2}{*}{\multicolumn{3}{|c|}{$\%$ Mortality }} & \multirow{2}{*}{\multicolumn{3}{|c|}{$\begin{array}{c}\% \text { Mortality } \\
\text { 1- dav old larvae }\end{array}$}} & \multicolumn{3}{|c|}{$\%$ Mortality } \\
\hline & & & \multicolumn{2}{|c|}{ Newly hatched larvae } & & & & \multicolumn{3}{|c|}{ 2- day old larvae } \\
\hline & & \multicolumn{9}{|c|}{ Biosect W.P } \\
\hline \multirow{17}{*}{ 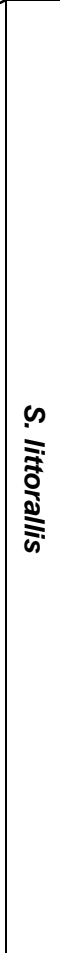 } & Period / days & 5 & 7 & 10 & 5 & 7 & 10 & 5 & 7 & 10 \\
\hline & $2 \times 0.10$ & $\begin{array}{c}70.0 \\
(30.0)\end{array}$ & $\begin{array}{c}76.0 \\
(24.0)\end{array}$ & $\begin{array}{c}84.0 \\
(16.0)\end{array}$ & $\begin{array}{c}50.0 \\
(50.0)\end{array}$ & $\begin{array}{c}56.0 \\
(44.0)\end{array}$ & $\begin{array}{c}68.0 \\
(32.0)\end{array}$ & $\begin{array}{c}42.0 \\
(58.0)\end{array}$ & $\begin{array}{c}50.0 \\
(50.0)\end{array}$ & $\begin{array}{c}56.0 \\
(44.0)\end{array}$ \\
\hline & $2 \times 0.25$ & $\begin{array}{c}74.0 \\
(26.0)\end{array}$ & $\begin{array}{l}80.0 \\
(20.0)\end{array}$ & $\begin{array}{c}86.0 \\
(14.0)\end{array}$ & $\begin{array}{c}52.0 \\
(48.0)\end{array}$ & $\begin{array}{c}62.0 \\
(38.0)\end{array}$ & $\begin{array}{c}70.0 \\
(30.0)\end{array}$ & $\begin{array}{c}45.0 \\
(55.0)\end{array}$ & $\begin{array}{c}54.0 \\
(46.0)\end{array}$ & $\begin{array}{c}60.0 \\
(40.0)\end{array}$ \\
\hline & $2 \times 0.50$ & $\begin{array}{c}82.0 \\
(18.0)\end{array}$ & $\begin{array}{c}86.0 \\
(14.0)\end{array}$ & $\begin{array}{c}90.0 \\
(10.0)\end{array}$ & $\begin{array}{c}58.0 \\
(42.0)\end{array}$ & $\begin{array}{c}66.0 \\
(34.0)\end{array}$ & $\begin{array}{c}74.0 \\
(26.0)\end{array}$ & $\begin{array}{c}50.0 \\
(50.0)\end{array}$ & $\begin{array}{c}60.0 \\
(40.0)\end{array}$ & $\begin{array}{c}68.0 \\
(32.0)\end{array}$ \\
\hline & $2 \times 0.75$ & $\begin{array}{c}86.0 \\
(14.0)\end{array}$ & $\begin{array}{c}88.0 \\
(12.0)\end{array}$ & $\begin{array}{l}92.0 \\
(8.0)\end{array}$ & $\begin{array}{c}62.0 \\
(38.0)\end{array}$ & $\begin{array}{c}68.0 \\
(32.0)\end{array}$ & $\begin{array}{c}80.0 \\
(20.0)\end{array}$ & $\begin{array}{c}56.0 \\
(44.0)\end{array}$ & $\begin{array}{c}66.0 \\
(34.0)\end{array}$ & $\begin{array}{c}72.0 \\
(28.0)\end{array}$ \\
\hline & $2 \times 1.0$ & $\begin{array}{c}90.0 \\
(10.0)\end{array}$ & $\begin{array}{l}92.0 \\
(8.0)\end{array}$ & $\begin{array}{l}94.0 \\
(6.0)\end{array}$ & $\begin{array}{c}66.0 \\
(34.0) \\
\end{array}$ & $\begin{array}{c}72.0 \\
(28.0) \\
\end{array}$ & $\begin{array}{c}86.0 \\
(14.0) \\
\end{array}$ & $\begin{array}{c}62.0 \\
(38.0) \\
\end{array}$ & $\begin{array}{c}70.0 \\
(30.0) \\
\end{array}$ & $\begin{array}{c}80.0 \\
(20.0) \\
\end{array}$ \\
\hline & $\begin{array}{l}\text { Control / } \\
\text { survival }\end{array}$ & 100 & 100 & 100 & 100 & 100 & 100 & 100 & 100 & 100 \\
\hline & L.S.D 0.05 & 2.05 & 2.15 & 3.01 & 1.09 & 1.66 & 1.02 & 2.55 & 2.11 & 2.02 \\
\hline & & \multicolumn{9}{|c|}{ Bioranza W.P } \\
\hline & Period / days & 5 & 7 & 10 & 5 & 7 & 10 & 5 & 7 & 10 \\
\hline & $2 \times 0.10$ & $\begin{array}{c}56.0 \\
(44.0)\end{array}$ & $\begin{array}{c}64.0 \\
(36.0)\end{array}$ & $\begin{array}{c}72.0 \\
(28.0)\end{array}$ & $\begin{array}{c}48.0 \\
(52.0)\end{array}$ & $\begin{array}{c}52.0 \\
(48.0)\end{array}$ & $\begin{array}{c}60.0 \\
(40.0)\end{array}$ & $\begin{array}{c}32.0 \\
(68.0)\end{array}$ & $\begin{array}{c}36.0 \\
(64.0)\end{array}$ & $\begin{array}{c}44.0 \\
(56.0)\end{array}$ \\
\hline & $2 \times 0.25$ & $\begin{array}{c}58.0 \\
(42.0)\end{array}$ & $\begin{array}{c}68.0 \\
(32.0) \\
\end{array}$ & $\begin{array}{c}74.0 \\
(26.0) \\
\end{array}$ & $\begin{array}{c}50.0 \\
(50.0) \\
\end{array}$ & $\begin{array}{c}58.0 \\
(42.0) \\
\end{array}$ & $\begin{array}{c}70.0 \\
(30.0)\end{array}$ & $\begin{array}{c}36.0 \\
(64.0)\end{array}$ & $\begin{array}{c}42.0 \\
(58.0) \\
\end{array}$ & $\begin{array}{c}56.0 \\
(44.0) \\
\end{array}$ \\
\hline & $2 \times 0.50$ & $\begin{array}{c}62.0 \\
(38.0)\end{array}$ & $\begin{array}{c}74.0 \\
(26.0)\end{array}$ & $\begin{array}{c}82.0 \\
(18.0)\end{array}$ & $\begin{array}{c}52.0 \\
(48.0)\end{array}$ & $\begin{array}{c}62.0 \\
(38.0)\end{array}$ & $\begin{array}{c}76.0 \\
(24.0)\end{array}$ & $\begin{array}{c}42.0 \\
(58.0)\end{array}$ & $\begin{array}{c}46.0 \\
(54.0)\end{array}$ & $\begin{array}{c}66.0 \\
(34.0)\end{array}$ \\
\hline & $2 \times 0.75$ & $\begin{array}{c}66.0 \\
(34.0)\end{array}$ & $\begin{array}{c}78.0 \\
(22.0)\end{array}$ & $\begin{array}{c}84.0 \\
(16.0)\end{array}$ & $\begin{array}{c}60.0 \\
(40.0)\end{array}$ & $\begin{array}{c}64.0 \\
(36.0)\end{array}$ & $\begin{array}{c}82.0 \\
(18.0)\end{array}$ & $\begin{array}{c}46.0 \\
(54.0)\end{array}$ & $\begin{array}{c}56.0 \\
(44.0)\end{array}$ & $\begin{array}{c}70.0 \\
(30.0)\end{array}$ \\
\hline & $2 \times 1.0$ & $\begin{array}{c}69.0 \\
(31.0) \\
\end{array}$ & $\begin{array}{c}83.0 \\
(17.0) \\
\end{array}$ & $\begin{array}{c}88.0 \\
(12.0) \\
\end{array}$ & $\begin{array}{c}64.0 \\
(36.0) \\
\end{array}$ & $\begin{array}{c}67.0 \\
(33.0) \\
\end{array}$ & $\begin{array}{c}83.0 \\
(17.0) \\
\end{array}$ & $\begin{array}{c}53.0 \\
(47.0) \\
\end{array}$ & $\begin{array}{c}61.0 \\
(39.0) \\
\end{array}$ & $\begin{array}{c}72.0 \\
(28.0) \\
\end{array}$ \\
\hline & $\begin{array}{l}\text { Control / } \\
\text { survival }\end{array}$ & 100 & 100 & 100 & 100 & 100 & 100 & 100 & 100 & 100 \\
\hline & L.S.D 0.05 & 1.05 & 1.09 & 2.1 & 0.04 & 0.75 & 0.80 & 0.54 & 1.62 & 1.89 \\
\hline
\end{tabular}

Table (6) show that the mortality percentages were 50.0, 40.0 and $34.0,60.0,44.0$ and $38.0,70.0,56.0$ and $40.0 \%$ at the lowest concentration $(0.1 \mathrm{mg} / \mathrm{ml})$ increased to $74.0,60.0$ and $50.0,80.0,65.0$ and 55.0, 86.0, 78.0 and $70.0 \%$ at the highest concentration $(1.0 \mathrm{mg} / \mathrm{ml})$ of Biosect on $A$. ipsilon after 5, 7 and 10 days, while the survival rate of larvae of the three age groups, in the control was $100 \%$ and the mortality percentages was $0.0 \%$. On the other hand, the mortality percentages in the three age- groups were 48.0 , 44.0 and 26.0, 52.048 .0 and 30.0 , and $62.0,54.038 .0 \%$ at the lowest concentration of Bioranza on A. ipsilon, increased to 67.0, 59.0 and 45.0, 74.0, 64.0 and 54.0, 80.0, 76.0 and $66.0 \%$ at the highest concentration after 5,7 and 10.0 days, while the survival $1^{\text {st }}$ instar age groups larvae was $100 \%$ and the mortality percentage was $0.0 \%$ in the control.

It was concluded that, the adverse effect of Biosect and Bioranza included decrease of larval percentage according to both concentration and age- group of larvae. Newly hatched larvae seemed to be more sever than other groups, while the opposite was true in the case of 1 and 2 -day old larvae. 
EL- Garhy, S. M. M.

Table (6): Efficienecy of Biosect and Bioranza formulations on A. ipsilon age - group larvae under semi field conditions.

\begin{tabular}{|c|c|c|c|c|c|c|c|c|c|c|}
\hline \multirow{4}{*}{\multicolumn{2}{|c|}{ Conc. }} & \multicolumn{9}{|c|}{ Age - group of $1^{\text {st }}$ instar larvae } \\
\hline & & \multicolumn{3}{|c|}{$\%$ Mortality r } & \multirow{2}{*}{\multicolumn{3}{|c|}{$\begin{array}{c}\% \text { Mortality } \\
\text { 1- day old larvae }\end{array}$}} & \multicolumn{3}{|c|}{$\%$ Mortality } \\
\hline & & \multicolumn{3}{|c|}{ Newly hatched larvae } & & & & \multicolumn{3}{|c|}{ 2- day old larvae } \\
\hline & & \multicolumn{9}{|c|}{ Biosect W.P } \\
\hline \multirow{17}{*}{ 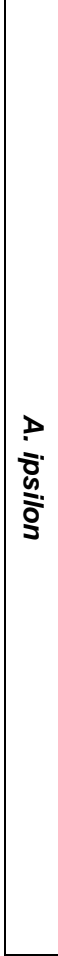 } & Period / days & 5 & 7 & 10 & 5 & 7 & 10 & 5 & 7 & 10 \\
\hline & $2 \times 0.10$ & $\begin{array}{c}50.0 \\
(50.0)\end{array}$ & $\begin{array}{c}60.0 \\
(40.0)\end{array}$ & $\begin{array}{c}70.0 \\
(30.0)\end{array}$ & $\begin{array}{c}440.0 \\
(60.0)\end{array}$ & $\begin{array}{c}44.0 \\
(56.0)\end{array}$ & $\begin{array}{l}56.0 \\
(44.0)\end{array}$ & $\begin{array}{c}34.0 \\
(66.0)\end{array}$ & $\begin{array}{c}38.0 \\
(62.0)\end{array}$ & $\begin{array}{c}40.0 \\
(60.0)\end{array}$ \\
\hline & $2 \times 0.25$ & $\begin{array}{c}52.0 \\
(48.0)\end{array}$ & $\begin{array}{c}66.0 \\
(34.0)\end{array}$ & $\begin{array}{c}76.0 \\
(24.0)\end{array}$ & $\begin{array}{c}46.0 \\
(54.0)\end{array}$ & $\begin{array}{c}48.0 \\
(52.0)\end{array}$ & $\begin{array}{c}60.0 \\
(40.0)\end{array}$ & $\begin{array}{c}36.0 \\
(64.0)\end{array}$ & $\begin{array}{c}36.0 \\
(64.0)\end{array}$ & $\begin{array}{c}44.0 \\
(56.0)\end{array}$ \\
\hline & $2 \times 0.50$ & $\begin{array}{c}60.0 \\
(40.0)\end{array}$ & $\begin{array}{c}70.0 \\
(30.0) \\
\end{array}$ & $\begin{array}{c}80.0 \\
(20.0)\end{array}$ & $\begin{array}{c}52.0 \\
(48.0) \\
\end{array}$ & $\begin{array}{c}54.0 \\
(46.0) \\
\end{array}$ & $\begin{array}{c}66.0 \\
(34.0) \\
\end{array}$ & $\begin{array}{c}40.0 \\
(60.0) \\
\end{array}$ & $\begin{array}{c}42.0 \\
(58.0) \\
\end{array}$ & $\begin{array}{c}48.0 \\
(52.0) \\
\end{array}$ \\
\hline & $2 \times 0.75$ & $\begin{array}{c}66.0 \\
(34.0) \\
\end{array}$ & $\begin{array}{c}76.0 \\
(24.0)\end{array}$ & $\begin{array}{c}86.0 \\
(14.0) \\
\end{array}$ & $\begin{array}{c}58.0 \\
(42.0) \\
\end{array}$ & $\begin{array}{c}62.0 \\
(38.0) \\
\end{array}$ & $\begin{array}{c}70.0 \\
(30.0) \\
\end{array}$ & $\begin{array}{c}48.0 \\
(52.0) \\
\end{array}$ & $\begin{array}{c}52.0 \\
(48.0)\end{array}$ & $\begin{array}{c}54.0 \\
(46.0) \\
\end{array}$ \\
\hline & $2 \times 1.0$ & $\begin{array}{c}74.0 \\
(26.0)\end{array}$ & $\begin{array}{c}80.0 \\
(20.0)\end{array}$ & $\begin{array}{c}86.0 \\
(14.0) \\
\end{array}$ & $\begin{array}{c}60.0 \\
(40.0) \\
\end{array}$ & $\begin{array}{c}65.0 \\
(35.0) \\
\end{array}$ & $\begin{array}{c}78.0 \\
(22.0)\end{array}$ & $\begin{array}{c}50.0 \\
(50.0)\end{array}$ & $\begin{array}{c}55.0 \\
(45.0) \\
\end{array}$ & $\begin{array}{c}70.0 \\
(30.0) \\
\end{array}$ \\
\hline & $\begin{array}{l}\text { Control / } \\
\text { survival }\end{array}$ & 100 & 100 & 100 & 100 & 100 & 100 & 100 & 100 & 100 \\
\hline & L.S.D 0.05 & 1.55 & 1.68 & 2.01 & 0.99 & 0.78 & 0.88 & 0.56 & 0.65 & 0.59 \\
\hline & & \multicolumn{9}{|c|}{ Bioranza W.P } \\
\hline & Period / days & 5 & 7 & 10 & 5 & 7 & 10 & 5 & 7 & 10 \\
\hline & $2 \times 0.10$ & $\begin{array}{c}48.0 \\
(52.0)\end{array}$ & $\begin{array}{c}52.0 \\
(48.0)\end{array}$ & $\begin{array}{c}62.0 \\
(28.0)\end{array}$ & $\begin{array}{c}44.0 \\
(56.0)\end{array}$ & $\begin{array}{c}48.0 \\
(52.0)\end{array}$ & $\begin{array}{l}54.0 \\
(46.0)\end{array}$ & $\begin{array}{l}26.0 \\
(74.0)\end{array}$ & $\begin{array}{l}30.0 \\
(70.0)\end{array}$ & $\begin{array}{c}38.0 \\
(62.0)\end{array}$ \\
\hline & $2 \times 0.25$ & $\begin{array}{c}56.0 \\
(44.0) \\
\end{array}$ & $\begin{array}{c}56.0 \\
(44.0)\end{array}$ & $\begin{array}{c}66.0 \\
(34.0) \\
\end{array}$ & $\begin{array}{c}46.0 \\
(54.0) \\
\end{array}$ & $\begin{array}{c}52.0 \\
(48.0) \\
\end{array}$ & $\begin{array}{c}58.0 \\
(42.0)\end{array}$ & $\begin{array}{c}38.0 \\
(62.0)\end{array}$ & $\begin{array}{c}38.0 \\
(62.0)\end{array}$ & $\begin{array}{c}48.0 \\
(52.0) \\
\end{array}$ \\
\hline & $2 \times 0.50$ & $\begin{array}{c}58.0 \\
(42.0)\end{array}$ & $\begin{array}{c}60.0 \\
(40.0)\end{array}$ & $\begin{array}{c}68.0 \\
(32.0)\end{array}$ & $\begin{array}{c}52.0 \\
(48.0)\end{array}$ & $\begin{array}{c}56.0 \\
(44.0)\end{array}$ & $\begin{array}{c}70.0 \\
(30.0)\end{array}$ & $\begin{array}{c}40.0 \\
(60.0)\end{array}$ & $\begin{array}{c}46.0 \\
(54.0)\end{array}$ & $\begin{array}{c}54.0 \\
(46.0)\end{array}$ \\
\hline & $2 \times 0.75$ & $\begin{array}{c}64.0 \\
(36.0)\end{array}$ & $\begin{array}{l}70.0 \\
(30.0)\end{array}$ & $\begin{array}{c}78.0 \\
(22.0)\end{array}$ & $\begin{array}{c}56.0 \\
(44.0)\end{array}$ & $\begin{array}{c}64.0 \\
(36.0)\end{array}$ & $\begin{array}{c}76.0 \\
(24.0)\end{array}$ & $\begin{array}{c}42.0 \\
(58.0)\end{array}$ & $\begin{array}{c}44.0 \\
(56.0)\end{array}$ & $\begin{array}{c}62.0 \\
(38.0)\end{array}$ \\
\hline & $2 \times 1.0$ & $\begin{array}{c}67.0 \\
(33.0) \\
\end{array}$ & $\begin{array}{c}74.0 \\
(26.0) \\
\end{array}$ & $\begin{array}{c}80.0 \\
(20.0) \\
\end{array}$ & $\begin{array}{c}59.0 \\
(41.0)\end{array}$ & $\begin{array}{c}64.0 \\
(34.0) \\
\end{array}$ & $\begin{array}{c}76.0 \\
(24.0) \\
\end{array}$ & $\begin{array}{c}45.0 \\
(55.0) \\
\end{array}$ & $\begin{array}{c}54.0 \\
(46.0) \\
\end{array}$ & $\begin{array}{c}66.0 \\
(34.0) \\
\end{array}$ \\
\hline & $\begin{array}{l}\text { Control / } \\
\text { survival }\end{array}$ & 100 & 100 & 100 & 100 & 100 & 100 & 100 & 100 & 100 \\
\hline & L.S.D 0.05 & 1.05 & 1.09 & 2.1 & 0.04 & 0.75 & 0.80 & 0.54 & 0.60 & 0.51 \\
\hline
\end{tabular}

\section{REFERENCES}

Amer, M. M.; El-Sayed, T. I.; Bakheit, H. K.; Moustafa, S. A.; El-Sayed, Y. A (2008):Pathogenicity and genetic variability of five entomopathogenic fungi against Spodoptera littoralis. Res. J. of Agric. and Biol. Sci.; 8. 4: 5, 354-367.

Bhattacharya, A.K.; Mondal, P Ramamurthy, V.V. and Srivastava R.P. (2003). Beauveria bassiana : apotential bioagent for innovative integrated pest management program. In: Srivastava, R.P Ed.), Biopesticides and Bioagents in Integrated Pest Management of Agricultural Crops. International Book Distributing Co. Lucknow 860 pp.

El-Hawary, F.M and Abd El-Salam, A.M.E (2009): Laboratory bioassay of some entomopathogenic fungi on Spodoptera littoralis (Boisd.)and Agrotis ipsilon (Hufn.) larvae (Lepidoptera: Noctuidae). Egypt. Acad. J. biol. Sci., 2 (2): 1 - 4 
El-Husseini, M. M.; Agamy, E. A.; Mesbah, A. H.; El-Fandary, O. O.; Abdallah, M. F.(2008):Using Beauveria bassiana (Bals.) Vuillemin in spraying and dusting applications for biological control of sugar beet insect pests in Egypt. Egy. J. of Biol. Pest Cont. 18: 2, 369-375.

Farag, N. A. (2008): Susceptibility of the cotton leaf worm, Spodoptera littoralis 3rd instar larvae to some bio-insecticides (Lepidoptera: Noctuidae). Egy. J. of Biol. Pest. Cont. Vol. 18 No. 2pp. $343-346$.

Garcia-Gutierrez, C.; Rosas-Garcia, N. M.; Norzagaray-Campos, M.; ChairezHernandez, I. (2010): Efficacy of Beauveria bassiana and Metarhizium anisopliae to control Pieris rapae on cabbage in the field. Southwestern Entomologist; 35: 1, 75-83.

Gardezi, S. R. A.(2006): Studies on the application of fungi and bacteria controlling insect pests in Azad Jammu and Kashmir, Pakistan. Arch. of Phytopath. and Plant Prot. 39: 1, 49-67.

Gomaa, A. E; Ibrahim, R. A. (2006): Laboratory evaluation of certain compounds on the cotton leaf worm Spodoptera littoralis(Boisd.) (Lepedoptera : Noctudae). Manufiya. J. Agric. Vol. 31 No. 5: 1281 1293

Gosselin, M. -E.; Belair, G.; Simard, L.; Brodeur, J. (2009): Toxicity of spinosad and Beauveria bassiana to the black cutworm, and the additivity of sub lethal doses. Biocon.Sci. and Tech, Vol. 19, No. 2, pp. 201-217(17).

Hosny, M. M., G. EL - Saadany, G. M. Moawad and C. Topper. (1993): Evaluation of efficacy of certain bacterial insecticides (Bacillius thuringiensis) in controlling Spodoptera littoralis in Egypt. Agric. Res. Rev., 61 (1), 45 - 56

Kao SueySheng (2007): Current status of bio-pesticides development, farmers' acceptance and utilization, and future perspective in Taiwan. Exten. Bull- Food \& Fert. Techn. Cen. 599, 20 pp.

Sabbour, M. M.; Sahab, A. F.(2005): Efficacy of some microbial control agents against cabbage pests in Egypt. Pakistan Journal of Biological Sciences; 8: 10, 1351-1356.

Sahab, A. F.; Sabbour, M. M. (2011): Virulence of four entomopathogenic fungi on some cotton pests with special reference to impact of some pesticides, nutritional and environmental factors on fungal growth. Egy. J.of Biol. Pest Cont.; 2011. 21: 1, 61-67.

Sun, Y. P. (1950): Toxicity index on improved method of comparing the relative toxicity of insecticides. J. Econ. Ent. 43: 45 - 53

Zaki, F. N.; Abdel-Raheem, M. A. (2010): Use of entomopathogenic fungi and insecticide against some insect pests attacking peanuts and sugar beet in Egypt. Arch. of Phytopath. and Plant Prot; 2010. 43: 16/18, 18191828. 


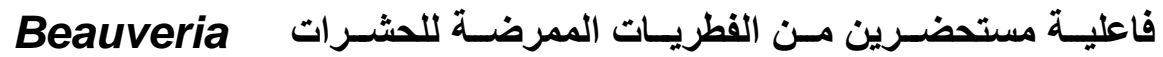

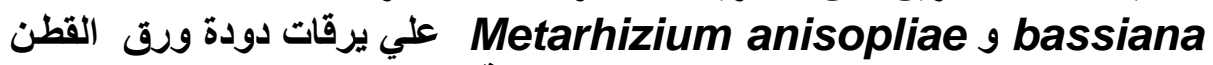
Agrotis ipsilon و والدودة القارضة السوداء سعهد بحوث وقاية النبات ـ مركيز الجارحي البحوث الزراعية ـ الدقي ـ الجيزة

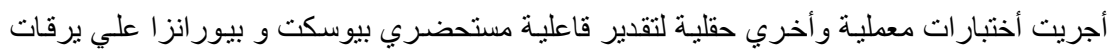

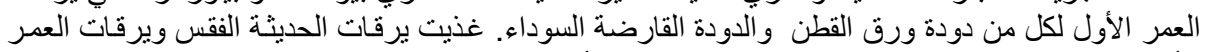

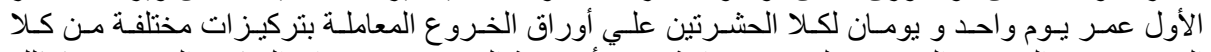

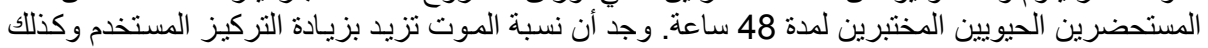

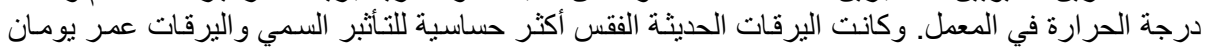

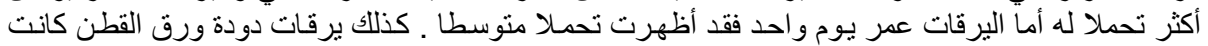

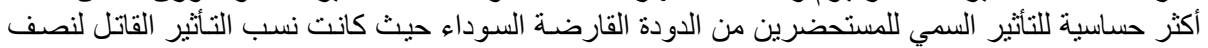

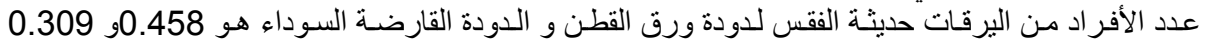

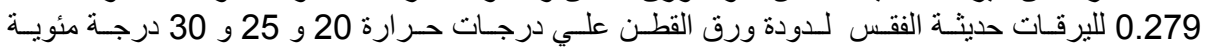

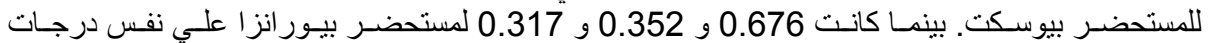

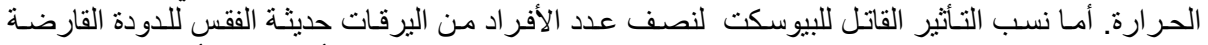

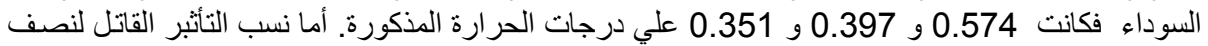

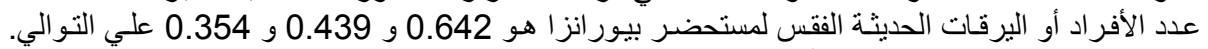

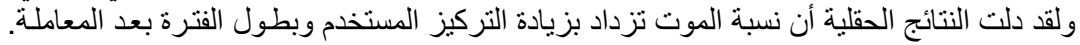

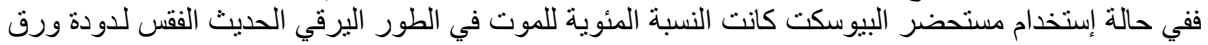

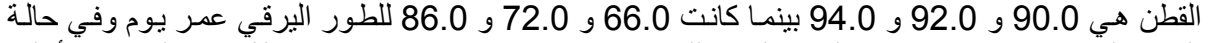
الطور اليرقي عمر يومان كانت النسبة المؤية للموت هي

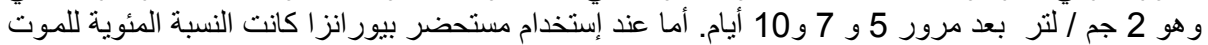
في الطور اليرقي الحديث الفقس هي

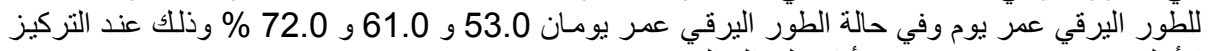

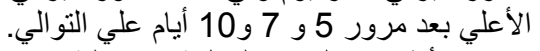

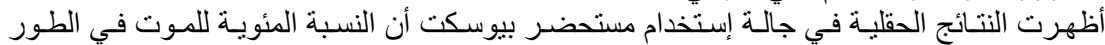

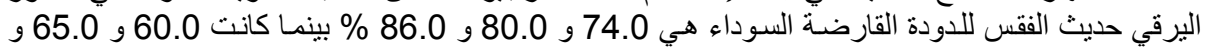

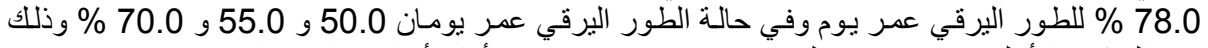

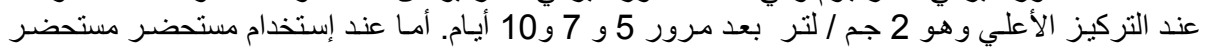

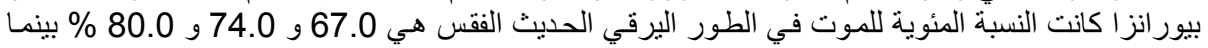

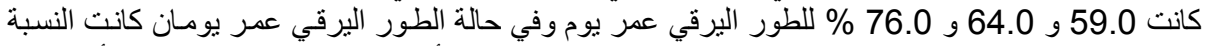
المئوية للموت هي 59.0 و 42.0 و 54.0 و 66.0 \% وذللك عند التركيز الأعلي بعد مرور اليرفي 5 و 7 و و10 أيام علي التوالي.

\author{
كلية الزراعة - جامعة المنصورة \\ مركز البحوث الزراعية
}

قام بتحكيم البحث

أ.د / عبد البديع عبد الحميد غانم

أ.د / احمد حسين الهنيدى البدي 